\title{
The Gendered Meanings of Assets for Divorce
}

Jeffrey P. Dew

Brigham Young University - Provo, jeff_dew@byu.edu

Follow this and additional works at: https://scholarsarchive.byu.edu/facpub

Part of the Other Social and Behavioral Sciences Commons

\section{Original Publication Citation}

Dew, J. P. (2009). The gendered meanings of assets for divorce. Journal of Family and Economic Issues, 30, 20-31.

\section{BYU ScholarsArchive Citation}

Dew, Jeffrey P., "The Gendered Meanings of Assets for Divorce" (2008). Faculty Publications. 4511. https://scholarsarchive.byu.edu/facpub/4511 accepted for inclusion in Faculty Publications by an authorized administrator of BYU ScholarsArchive. For more information, please contact ellen_amatangelo@byu.edu. 


\title{
The Gendered Meanings of Assets for Divorce
}

\author{
Jeffrey Dew
}

Published online: 9 December 2008

(C) Springer Science+Business Media, LLC 2008

\begin{abstract}
Scholars identified a negative relationship between assets and divorce decades ago, but the mechanisms behind this relationship remain unknown. Using data from the National Survey of Families and Households ( $N=4,721$ couples), this study compared three mechanisms that might link assets and divorce. Non-proportional Cox hazard models indicated that two of the three mechanisms explained the relationship between assets and divorce. Wives' marital satisfaction and their perceptions of their hypothetical post-divorce standard of living completely mediated the relationship between assets and divorce. The relationship between assets and divorce was not related to husbands' characteristics.
\end{abstract}

Keywords Assets - Commitment - Divorce - Gender . Marital satisfaction

Because contemporary married couples cannot take marital permanence for granted, they may take a financial risk by jointly accumulating assets. Although wealth can decrease the economic shock of divorce for dual-earner couples that have relatively equal incomes (Finke and Pierce 2006), divorce is devastating to couples' net-worth when assets are divided (Zagorsky 2003a). Despite these risks, contemporary married couples continue to accumulate assets

Portions of this study were presented at the 2005 annual conference of the National Council on Family Relations.

J. Dew $(\bowtie)$

Department of Sociology, University of Virginia, 542 Cabell Hall, P.O. Box 400766, Charlottesville, VA 22904-4766, USA e-mail: jpd197@juno.com and the majority of married couples hold their assets jointly (Fletschner and Klawitter 2005).

Ironically, holding assets jointly may decrease couples' risk of divorce; financial assets and divorce negatively relate. Although researchers have known of this association for over 50 years (Locke 1951), the mechanisms that link assets and divorce have rarely been tested. Consequently, it is unknown whether the relationship between assets and divorce occurs because assets increase the attractiveness of the marriage, raise the cost of divorce, or because stably and happily married couples have more incentives to accumulate assets and have fewer incentives to separate. Further, research has not explored gender differences in the relationship between assets and divorce.

Studying the relationship between assets and divorce may show how these two factors relate to wives' wellbeing. If, for example, assets keep women in unhappy marriages, their physical and mental health may suffer (Hawkins and Booth 2005). Further, although women experience less intense economic consequences following divorce now than in the past (McKeever and Wolfinger 2001), divorce still has greater economic consequences for women than for men (Daniels et al. 2006; McKeever and Wolfinger 2001; Morgan et al. 1992; Smock et al. 1999). Thus, the possibly gendered mechanisms that explain the relationship between assets and divorce may relate to women's economic well-being following divorce. For example, although assets may reduce the likelihood of divorce because wives do not want to live at a lower standard of living, when it does occur women with assets would have more economic resources. The relationships between gender, marriage, and assets have been understudied even though these factors are all potential sources of wellbeing and inequality (Schmidt and Sevak 2006). 
This study compares three mechanisms derived from social exchange theory in an attempt to explain the relationship between assets, divorce, and gender. The analyses use data from two waves of the National Survey of Families and Households, a nationally representative longitudinal study.

\section{Previous Studies of Assets and Divorce}

The relationship between assets and divorce has been known for a long time. In the mid-twentieth century, researchers found a positive cross-sectional association between assets and marital satisfaction, and a negative cross-sectional association between assets and divorce (Levinger 1965; Locke 1951). Later, longitudinal data demonstrated that assets negatively predicted divorce over time (Booth et al. 1986; Galligan and Bahr 1978; Schaninger and Buss 1986 though see Sanchez and Gager 2000 who found no relationship). Interestingly, assets predicted divorce better than income (Galligan and Bahr 1978).

Recently, studies have moved away from analyzing the preventive nature of assets on divorce and have focused instead on married couples' asset changes as they stayed married or progressed toward divorce. For example, the longer individuals remained married the more assets they accumulated (Hao 1996). Married individuals also had higher rates of asset accumulation than both single individuals and formerly married individuals (Zagorsky 2003a). Further, couples began spending down their wealth prior to divorce (Zagorsky 2003a), unless they earned about the same amount of money (Finke and Pierce 2006). Because of this shift in focus, the mechanisms behind the relationship between assets and divorce have still not been fully explored.

\section{The Different Meanings of Assets in Social Exchange Theory}

Social exchange theory offers explanations for relationship development and dissolution. Utilizing familiar principles of reward maximization and cost minimization, exchange theory explains that spouses compare the rewards and costs (called "outcomes") of their marriage with their relationship expectations (called the "comparison level") (Nye 1979; Thibault and Kelley 1959). If over many interactions, spouses feel that their marital outcomes (e.g., benefit/ cost ratios) exceed their comparison level, then they will be satisfied with the relationship. Conversely, if the outcomes fall below the comparison level, then spouses will be dissatisfied with the relationship.
In social exchange theory, marital dissolution is thought to occur when spouses' outcomes fall below the "comparison level for alternatives" or " $\mathrm{CL}_{\mathrm{Alt}}$ " (Thibault and Kelley 1959). The $\mathrm{CL}_{\mathrm{Alt}}$ is the lowest level of outcomes a spouse will accept without moving to dissolve the marriage. Below this point, a spouse feels that his or her alternatives to the marriage (including living alone) will yield better outcomes than the marriage offers. The attractiveness of alternatives to marriage is inversely related to a spouse's dependency on the marriage. That is, if they want to leave but cannot because of few alternatives they are more likely to remain in the marriage. Thus, for example, an individual who does not depend on their spouse for economic support might view divorce as a viable alternative to the marriage; an individual who is completely dependent on their spouse for economic support might not.

The factors that make up exchange theory (e.g., rewards, costs, comparison level, and comparison level of alternatives) can change over time. For example, if spouses frequently experience outcomes that exceed their comparison level or expectations, they stop making exchange comparisons (Levinger 1976; Nye 1982). As spouses begin to experience dissatisfaction with their relationship, however, exchange becomes more salient and they may tend to disregard potential future rewards from the marriage (Levinger 1976; Sabatelli 1999).

Changes in these factors may also be mutually reinforcing. Spouses who are more likely to think about and monitor the costs of the marriage, and who expect quick reciprocal behavior from their spouse when they behave positively, are more likely to be dissatisfied with their relationship (Buunk and Van Yperen 1991; Fincham and Beach 1999). Further, men and women that are dissatisfied with their marriages attend more to alternatives to the marriage (e.g., the $\mathrm{CL}_{\mathrm{Alt}}$ by viewing members of the opposite sex more positively (Miller 1997).

Marital rewards, costs, comparison levels, and comparison level of alternatives work together and offer three competing mechanisms that relate financial assets and divorce. The first mechanism is selection, which asserts that the negative relationship between assets and divorce is spurious. A second possibility is that assets help spouses enjoy their marriage more and thus make divorce less likely. A final mechanism is that assets may keep individuals from divorcing by reducing the $\mathrm{CL}_{\mathrm{Alt}}$ (e.g., by making divorced living seem less plausible).

Assets, Divorce, and Selection

The simplest explanation for assets predicting divorce is selection. That is, couples who are less likely to divorce are also more likely to accumulate assets. Social exchange 
theory supports a selection explanation because it predicts that those who are the most likely to accumulate assets are also those who are the least likely to divorce. Social exchange theory asserts that individuals who have the most to gain by maintaining their marriage will invest the most in it, whereas those with the least to lose by its dissolution will invest the least (Nye 1982; Sabatelli 1999). Applying this to marital satisfaction suggests that individuals who are happy in their marriage have more to gain by increasing their marital investments (e.g., by increasing their jointlyheld assets). But because they are happy in their marriage they are also less likely to divorce. Thus, spouses that are satisfied with their marriage will be more likely to accumulate assets and also be less likely to divorce. Because marital satisfaction may be associated with increased assets levels and decreased divorce probabilities, this creates the illusion that assets and divorce are somehow linked.

Perceived marital stability is another variable that may spuriously link assets and marital stability. Individuals who perceive that their marriage is stable can invest in their marriage with less risk (Cherlin 2004; Pollak 1985). When couples divorce, they lose "relationship specific" investments they have made (e.g., time and effort) because these types of investments will not transfer to new relationships. This loss also applies to jointly-held financial assets because they are divided during the divorce settlement (England and Farkas 1986). Consequently, individuals who feel more confident about the stability of their marriage can more aggressively accumulate assets than individuals who are unsure about their marriages. Further, if their perceptions of marital stability are correct then they are less likely to divorce.

Marital satisfaction and perceived marital stability may be more selective for husbands than for wives. Most husbands outearn their wives, and most married couples pool their income (Heimdal and Houseknecht 2003; Winkler et al. 2005). Thus, husbands convert more of their income into joint assets than wives, and would have more of an investment to lose in the event of a divorce. Consequently, husbands may be more reluctant than wives to accumulate jointly-held assets unless they are happy and perceive that they have a stable union.

Hypothesis 1 Marital satisfaction and perceived marital stability predict both asset accumulation and lower divorce likelihoods. These selection issues explain the relationship between assets and divorce more for husbands than for wives.

\section{Assets Fulfilling Marital Expectations}

Although scholars can use social exchange theory to explain why a spurious relationship between assets and divorce may exist, the theory also suggests that assets may fulfill marital expectations and thus lead to less divorce. In a classic treatise on relationship dissolution, under a heading titled "Marital Attractions," Levinger (1976) wrote,

... couple property, if it represents a truly joint investment, may add to the stability of the relationship. To the extent that partners have consulted mutually in acquiring the property, and that it symbolizes what they both treasure, joint property would be a strength rather than a weakness of their relationship" (p.31).

Levinger's (1976) idea can be restated in the language of social exchange theory: married couples expect to jointly accumulate assets and when they meet this expectation, they are less likely to divorce. Thus, accumulating assets helps couple's marital outcomes to exceed their CL.

Some studies suggest that married couples do expect to accumulate assets. Social norms regarding marriage include being financially stable prior to and during the marriage (Edin 2001; Smock et al. 2005). Spouses expect to buy a home, save for children's college education, and build a retirement fund (Townsend 2002; Waite and Gallagher 2000). Expectations of financial wellbeing may also compliment marital expectations of permanence and commitment (Cherlin 2004; Pollak 1985) and help couples accumulate more assets. If accumulating assets helps couples to meet their marital expectations, then marital satisfaction should mediate the relationship between assets and divorce. That is, assets should positively predict marital satisfaction, which would then relate to a lower likelihood of divorce.

Like selection, this satisfaction hypothesis may be more appropriate for husbands than for wives. Husbands may view asset accumulation, especially home ownership, as a means of enacting their provider role. Although marriage has become more egalitarian now than in the past, both women and men expect husbands to economically provide for their families (Smock et al. 2005). In addition to providing a stable income, men want to provide their families with a home, education, etc. (Townsend 2002). In support of the idea that husbands feel validated in their roles by accumulating assets, research has shown that husbands report their net-worth to be $30 \%$ higher than their wives report (Zagorsky 2003b). That is, when asked, husbands may inflate their net-worth to show that they are behaving appropriately as breadwinners.

Hypothesis 2a Marital satisfaction mediates the relationship between assets and divorce for husbands.

Levinger's (1976) assertions about couples' assets bring up issues of fairness. Levinger stated that both spouses 
must value the assets they accumulate if assets are to serve as an attraction to the marriage. Assets would not help a couple's marital satisfaction if one spouse unilaterally uses discretionary income to accumulate more assets while the other spouse would rather use discretionary income to increase consumption. In such a situation, either spouse may feel unfairly dealt with, and the assets may remind them of the unfairness in the marriage. Fairness in money making decisions is related to marital satisfaction and stability (Schaninger and Buss 1986). Thus, the ability for assets to act as an attraction to the marriage depends on whether spouses feel they have an equitable say in how money is used in the marriage.

Hypothesis 2b Perceptions of financial unfairness will moderate the relationship between marital satisfaction and divorce.

\section{Assets as Barriers to Divorce}

Rather than enhancing the attractiveness of the marriage by helping marital outcomes to exceed couples' CL, assets may relate to less divorce by decreasing the attractiveness of divorce (e.g., lowering the $\mathrm{CL}_{\mathrm{Alt}}$ ). Asset accumulation decreases the attractiveness of divorce because couples must divide their assets when they separate (Johnson 1991; Zagorsky 2003a). In addition to having a lower net-worth, the process of liquidating and dividing assets may force individuals to live at a lower standard of living following a divorce. Individuals would know that they will have to live in a smaller home, for example, if the home they jointly own will be sold during a divorce. Maritally dissatisfied individuals may consider both these factors as they think about the alternatives to their marriage.

Although the difference is subtle, these two mechanisms (assets meeting expectations versus assets lowering the attractiveness of divorce) are different and have different consequences. Marital attractions enhance marital quality, while barriers to divorce simply make it more difficult to divorce regardless of the marital quality (Johnson 1991; Johnson et al. 1999). As an attraction to the marriage, assets would help spouses feel satisfied in their marriage. As barriers to divorce, assets would keep individuals from divorcing but do nothing to enhance their feelings toward their marriage.

Structural commitment is a term indicating how much an individual spouse feels compelled to remain in the marriage because of the barriers to divorce (Johnson 1991). These barriers may include difficulty in accessing divorce procedures or having few viable alternatives to the marriage. Consequently, assets may be a form of structural commitment because they may prevent divorce by decreasing the likelihood that spouses' would want to live at a lower post-divorce standard of living.
Interestingly, spouses do not attend to structural commitment unless they are unhappy in their marriages. Both qualitative and quantitative research has shown that barriers to divorce are much more salient for unhappy spouses (Johnson 1991; Johnson et al. 1999; Previti and Amato 2003). Happily married spouses simply have no reason to consider whether various aspects of their lives prevent them from divorcing. Thus, a marital satisfaction by structural commitment interaction term is included in the models testing this mechanism.

Assets are more likely to be associated with wives' feelings of structural commitment than of husbands' feelings. Wives still have less economic power in marriage than husbands, and even when wives earn more than their husbands, they often have less power in the marriage (Biddlecom and Kramarow 1998; Tichenor 1999; Winkler et al. 2005). Additionally, the economic consequences of divorce are harsher for women than for men (Bianchi et al. 1999). Divorced women often have to increase their work participation prior to or following divorce (Gerner et al. 1990; Trzcinski 1996), and divorced fathers often fail to pay child support or pay their full amount (Coleman and Ganong 1992). Given wives' economic disadvantages in marriage and divorce relative to their husbands, wives may be more reticent to divorce if it means losing assets.

Hypothesis 3 Structural commitment mediates the relationship between assets and divorce for wives, but only for dissatisfied wives.

\section{Method}

Data and Sample

This study used data from the National Survey of Families and Households (NSFH). The NSFH is a nationally representative longitudinal data set on family life that included information on participants' marital and financial situations. Participants and their spouses were interviewed in 1987-1988 and 1992-1994. The sample used in this study included individuals who were married at the first wave, and whose spouse participated in both Wave 1 (W1) and Wave 2 (W2). Further, if the participants divorced their divorce date had to be between W1 and W2 (some couples had illogical divorce dates). 4,721 married couples met the selection criteria.

An additional 898 couples met all of the selection criteria, but did not participate in W2 of the NSFH. The couples who left the sample were older, had longer marital durations, were slightly less educated, and had lower asset and income levels. In all marital respects, however, they were equal to the individuals that stayed in the study (e.g., 
they had similar marital satisfaction, similar ratings of perceived marital stability, etc.). Since the couples that did not participate in W2 had marriages that were comparable to the other participants' they may have had similar divorce rates. If they had participated in W2 and been included in this study, couples that left the NSFH may have lowered the relationship between assets and the likelihood of divorce (since they had lower assets). Thus, the results from this study must be interpreted in light of the attrition.

Despite the attrition problem, I used the NSFH for this study because the data had unique characteristics that helped address the hypotheses. First, the NSFH was one of the few studies to combine detailed questions about couples' assets with questions about their marriage. Second, the NSFH surveyed both spouses in most households. This feature enabled gendered analyses to be run without any appreciable loss of statistical power. Further, when husbands and wives were analyzed separately, the relative weight of husbands' characteristics and wives' characteristics in the relationship between assets and divorce could be compared.

Table 1 shows the descriptive statistics for participants. Participants were generally satisfied in their marriages (the mean was six with a maximum of seven), perceived that their marriages would last (a mean of 4.5 with a maximum score of five) and most felt that the way money was handled in the marriage was fair to themselves. The average age of the participants was between 40 and 44 years-old, most participants were European-American, and were in their first marriage. Despite reports of high marital satisfaction and stability in $\mathrm{W} 1,11 \%$ of the couples ended their marriage between $\mathrm{W} 1$ and W2 (see Table 1). The mean length of time to divorce was 40.86 months or about 3.5 years.

\section{Measures}

Because the analyses were Cox hazards models, divorce was operationalized as the number of months until couples experienced a divorce or were right censored (e.g., ended the study without experiencing divorce). Couples' months in the study started at W1 when all of the covariates were first measured. Months of survival in the study were calculated by subtracting the month of the divorce from the month of the $\mathrm{W} 1$ interview. If couples were right censored, months of survival were calculated by subtracting the month of the W2 interview of the couples from the month of the W1 interview.

Couples' assets were measured by summing couples' savings (e.g., money market and savings accounts), financial investments (e.g., stocks and bonds), and net-worth of their home. Unfortunately, the NSFH measured assets jointly even if they were not truly held jointly. The distribution of the assets variable was highly skewed. To reduce the skew, the assets variable was transformed using a logarithmic (base 10) transformation.

Marital satisfaction was assessed using an item that asked couples how satisfied they were with their marriage

Table 1 Descriptive statistics

\begin{tabular}{|c|c|c|c|c|c|c|}
\hline \multirow[t]{2}{*}{ Individual variables } & \multicolumn{3}{|l|}{ Wives } & \multicolumn{3}{|c|}{ Husbands } \\
\hline & $M$ & $S D$ & Range & $M$ & $S D$ & Range \\
\hline W1 Marital satisfaction & 6.05 & 1.25 & $1-7$ & 6.12 & 1.19 & $1-7$ \\
\hline W1 Perceived stability & 4.61 & .72 & $1-5$ & 4.62 & .71 & $1-5$ \\
\hline W1 Financial unfairness & .12 & .38 & $0-2$ & .09 & .33 & $0-2$ \\
\hline W1 Structural commitment & 3.84 & .85 & $1-5$ & 3.56 & .89 & $1-5$ \\
\hline W1 Age & 40.54 & 14.40 & $16-97$ & 43.16 & 14.88 & $19-89$ \\
\hline W1 Education & 12.73 & 2.64 & $0-20$ & 12.82 & 3.14 & $0-20$ \\
\hline Black $^{\mathrm{a}}$ & .10 & .30 & $0-1$ & .10 & .30 & $0-1$ \\
\hline Other race ${ }^{a}$ & .07 & .25 & $0-1$ & .07 & .25 & $0-1$ \\
\hline Marital number & 1.25 & .52 & $1-6$ & 1.27 & .55 & $1-5$ \\
\hline Couple variables & \multicolumn{2}{|l|}{$M$} & \multicolumn{2}{|l|}{$S D$} & \multicolumn{2}{|l|}{ Range } \\
\hline Divorce & \multicolumn{2}{|l|}{.11} & \multicolumn{2}{|l|}{.31} & \multicolumn{2}{|l|}{$0-1$} \\
\hline Months until divorce & \multicolumn{2}{|l|}{40.86} & \multicolumn{2}{|l|}{20.92} & \multicolumn{2}{|l|}{$0-80$} \\
\hline W1 Assets & \multicolumn{2}{|l|}{$\$ 30,000^{\mathrm{b}}$} & \multicolumn{2}{|l|}{$\$ 116,835$} & \multicolumn{2}{|l|}{$\$ 0-4,265,001$} \\
\hline W1 Family income & \multicolumn{2}{|l|}{$\$ 31,200^{\mathrm{b}}$} & \multicolumn{2}{|l|}{$\$ 43,551$} & \multicolumn{2}{|l|}{$\$ 0-982,000$} \\
\hline W1 Marital duration & \multicolumn{2}{|l|}{16.09} & \multicolumn{2}{|l|}{14.30} & \multicolumn{2}{|l|}{$0-63$} \\
\hline
\end{tabular}

${ }^{\text {a }}$ Omitted category $=$ White, Non-Hispanic

b Sample median 
overall. Participants could respond that they were one (very dissatisfied) to seven (very satisfied).

Perceived marital stability was measured by an item that asked individuals to rate the chances that their marriage would dissolve. The response set ranged from one (very low) to five (very high). The responses were reverse coded so that higher scores represented higher perceived marital stability.

Perceived financial unfairness in money asked how fairly participants felt spending money was handled in the relationship. The responses ranged from one (Very Unfair to Me) to five (Very Unfair to Spouse) with three indicating no unfairness. Since perceived unfairness to oneself was the important factor in determining whether assets were an attraction to the marriage (Levinger 1976), the scores were first reverse coded so that higher scores represented more unfairness to self. Then three was subtracted from each score, and each score below zero was set to zero because scores below zero did not indicate any unfairness to the participant.

Structural commitment was operationalized using an item that asked participants how their standard of living would be affected by divorce. Individuals could respond from one (Standard of Living Would be Much Worse) to five (Standard of Living Would be Much Better). This item was reverse coded so that the higher an individual scored, the more negatively divorce would affect their standard of living and the more they experienced structural commitment.

The models also control for W1 measures of age, marital duration, income, education, and the number of children. Although the independent variables could be constructed as time varying, they could not be used as such because only two waves were used. Were time varying covariates included, they would have been confounded with changes (e.g., divorce) that occurred between W1 and W2. Thus, none of the variables in the analyses were time varying covariates.

Some of the measures had missing responses. In order to use data from participants with missing responses, multiple imputation techniques were used.

\section{Analyses}

To analyze the selection hypothesis, W1 assets were regressed on W1 marital satisfaction, W1 perceived marital stability and the control covariates. This tested whether satisfaction and perceived stability predicted high assets as stated in the selection hypothesis.

The other two mechanisms (assets raising satisfaction, or assets as barriers to divorce) were tested using a three step process to test mediation effects (Baron and Kenny 1986). First, the main independent variable-assets, had to predict the purported mediator variables - marital satisfaction, and structural commitment. This was accomplished by regressing the marital satisfaction and structural commitment onto assets and the control variables.

After showing that the independent variable predicted the mediator variables, the second step of establishing a mediation model was to run an analysis of the independent variable and dependent variable without the mediators. The third step was to run an analysis with the mediator variables. If the main independent variable was significant before the addition of the mediator variables, but less significant afterward, the mediation model was accepted. Consequently, the second and third steps of evaluating the satisfaction and barrier hypotheses used Cox hazards regressions to test the relationship between assets and divorce. That is, the Cox hazard regressions first showed whether the independent variable (assets) predicted the hazard of divorce in each month. Then the models were run with the mediator variables of marital satisfaction and structural commitment.

Using non-proportional hazard models was advantageous over other types of common analyses used in divorce research (e.g., logistic regression) for a number of reasons. First, they explicitly treated time as a variable rather than simply assessing whether an event occurred. Thus, they could show how assets related to the timing of the divorce in addition to predicting whether or not it occurred. Second, they statistically corrected for the fact that some of the right censored cases may in fact experience divorce in the future (Blossfeld and Rohwer 2002). Third, hazard regression models make no assumption about the underlying shape of the distribution of divorce that occurred (Allison 1995; Blossfeld and Rohwer 2002). This is a useful property for this particular analysis because no models of the hazard of divorce exist. I was hesitant to run a parametric model given how much results can change depending on the model used (Blossfeld and Rohwer 2002). Thus, the hazard models allowed me to use an event history analysis framework without being tied to a particular shape of the likelihood of divorce.

Initially, the analyses were intended to be proportional Cox hazards models. However, interacting the main independent variables with time showed that the hazard curves were not proportional (see interactions in Tables 4, 5). Proportional hazards models assume that the hazard (or likelihood) of divorce for two different groups (e.g., those with assets and those without assets) is the same ratio no matter how many months of marriage have elapsed. For example, the proportional models assume that the ratio of the likelihood of divorce for those with assets and those without assets is the same in the first month of the study as the twentieth month of the study. This assumption was not met. To correct this problem, non-proportional hazards models were used. That is, all 
Table 2 OLS Predictions of couples' assets

\begin{tabular}{lcc}
\hline & Husbands & Wives \\
\hline Intercept & $-4.32^{* * *}$ & $-4.62^{* * *}$ \\
Marital satisfaction & -.001 & .02 \\
Perceived marital stability & .06 & .05 \\
Family income $^{\mathrm{a}}$ & $.22^{* * *}$ & $.22^{* * *}$ \\
Marital duration & $.01^{* * *}$ & $.01^{*}$ \\
Age & $.03^{* * *}$ & $.03^{* * *}$ \\
Marital number & $-.13^{* *}$ & $.12^{*}$ \\
Education & $.15^{* * *}$ & $.18^{* * *}$ \\
Black & $-.63^{* * *}$ & $-.76^{* * *}$ \\
Other race $^{\mathrm{b}}$ & $-.62^{* * *}$ & $-.62^{* * *}$ \\
$R^{2}$ & .25 & .26 \\
\hline
\end{tabular}

${ }^{\mathrm{a}} \log 10$ Transform

b Omitted category $=$ White, Non-Hispanic

$* p<.05 ; * * p<.01 ; * * * p<.001$

the models contained an interaction terms where the main independent variables were interacted with the log transformation of months in the study. Introducing these interactions is an effective way to correct models when the proportional hazards assumption is not met (Allison 1995; Blossfeld and Rohwer 2002).

All of the analyses were run separately by gender. Because the NSFH surveyed both husbands and wives in a couple, the data were clustered. Using pooled clustered data often results in biased estimates (Raudenbush and Bryk 2002). These biased estimates would have resulted even if the participants were pooled and an asset by gender interaction term was included. Thus, running the analyses separately had the advantage of producing estimates free of the bias that would have resulted from the clustering. It also had the advantage of assessing husbands' and wives' different contributions to the relationship between assets and divorce.

\section{Results}

\section{Selection}

The results did not support the selection hypothesis. Neither husbands' nor wives' marital satisfaction nor their perceived marital stability at $\mathrm{W} 1$ was related to $\mathrm{W} 1$ assets (see Table 2). Although many of the control variables predicted assets (explaining 25\% of the variance), marital satisfaction and perceived marital stability were not statistically significant. If selection on these two variables explained the relationship between assets and divorce, they would have significantly predicted assets.

\section{Assets as Attractions to Marriage/Barriers to Divorce}

The first step of the mediation models showed that the mechanisms that relate assets and divorce probably worked through wives, but not husbands. W1 assets were unrelated to husband's marital satisfaction and feelings of structural commitment (See Table 3). However, assets positively predicted both wives' marital satisfaction and feelings of structural commitment $(b=.03, p<.05 ; b=.05$, $p<001$, respectively).

As expected, the hazard regression models were different for wives and husbands. Thus, the results will be discussed separately by gender. In the model with just assets and the control variables, assets negatively predicted divorce (Table 4, Attraction Model 1). That is, for every 10 fold increase in assets, the hazard ratio of divorce decreased by $7 \%$. Interestingly, however, the asset by time interaction was significant. To understand this interaction, all significant variables were held at their means, and various months and asset levels were entered into the regression to obtain predicted hazards. As shown in Fig. 1, assets' negative relationship with divorce attenuated over time (see Fig. 1). Thus for example, in the 6th month following W1 of the NSFH, couples with no assets were
Table 3 OLS Evaluations of the mediation variables

\footnotetext{
${ }^{\text {a }}$ Log 10 Transform

${ }^{\mathrm{b}}$ Omitted category $=$ White, Non-Hispanic

$* p<.05$; ** $p<.01$; $* * * p<.001$
}

\begin{tabular}{lclcc}
\hline & $\begin{array}{l}\text { Husbands' marital } \\
\text { satisfaction }\end{array}$ & $\begin{array}{l}\text { Husbands' structural } \\
\text { commitment }\end{array}$ & $\begin{array}{l}\text { Wives' marital } \\
\text { satisfaction }\end{array}$ & $\begin{array}{l}\text { Wives' structural } \\
\text { commitment }\end{array}$ \\
\hline Intercept & -.01 & .04 & $.32^{*}$ & .12 \\
W1 Assets & .01 & -.009 & $.03^{*}$ & $.05^{* * * *}$ \\
Family income & -.02 & .01 & $-.04^{* *}$ & .01 \\
Marital duration & .002 & $.006^{* *}$ & $-.006^{*}$ & $.008^{* * *}$ \\
Age & .003 & $.004^{*}$ & $.006^{*}$ & -.002 \\
Marital number & .04 & -.06 & $-.12^{* *}$ & .008 \\
Education & -.007 & $-.02^{* * *}$ & -.01 & $-.01 * *$ \\
Black & -.11 & $-.21^{* * *}$ & $-.27^{* * *}$ & $-.42^{* * *}$ \\
Other race $^{\mathrm{b}}$ & $.15^{*}$ & .005 & .10 & $-.14^{* *}$ \\
$R^{2}$ & .01 & .04 & .01 & .05 \\
\hline
\end{tabular}


Table 4 Wives' non-proportional hazards ratios of the relationship between assets and divorce

\begin{tabular}{|c|c|c|c|c|c|c|}
\hline & \multicolumn{3}{|c|}{ Assets as attractions to the marriage } & \multicolumn{3}{|c|}{ Assets as barriers to divorce } \\
\hline & Model 1 & Model 2 & Model 3 & Model 1 & Model 2 & Model 3 \\
\hline W1 Assets ${ }^{\mathrm{a}}$ & $.93^{*}$ & .98 & $.92 *$ & $.93 *$ & .97 & .99 \\
\hline W1 Financial unfairness & & 1.09 & 1.16 & & & \\
\hline W1 Marital satisfaction & & $.76 * * *$ & $.75 * * *$ & & & $.76 * * *$ \\
\hline Asset by unfairness interaction & & & .98 & & & \\
\hline Asset by satisfaction interaction & & & .98 & & & \\
\hline Structural commitment & & & & & $.80 * * *$ & $.82 * * *$ \\
\hline Commitment by satisfaction interaction & & & & & & .97 \\
\hline Family income $^{\mathrm{a}}$ & 1.03 & .98 & 1.01 & 1.03 & 1.02 & .99 \\
\hline Marital duration & .99 & .99 & .99 & .99 & .99 & .98 \\
\hline Age & $.93 * * *$ & $.93 * * *$ & $.94 * * *$ & $.93 * * *$ & $.93 * * *$ & $.94 * * *$ \\
\hline Marital number & $1.84 * * *$ & $1.80 * * *$ & $1.68 * * *$ & $1.84 * * *$ & $1.85^{* * *}$ & $1.63 * * *$ \\
\hline Education & .97 & .97 & .97 & .97 & .97 & .97 \\
\hline Black $^{\text {b }}$ & $1.42 *$ & 1.32 & 1.31 & $1.42 *$ & 1.22 & 1.31 \\
\hline Other race ${ }^{b}$ & .95 & 1.03 & 1.04 & .95 & .95 & 1.05 \\
\hline Asset $*$ time interaction & $1.84 * * *$ & $1.65 * * *$ & $2.25 * * *$ & $1.84 * * *$ & $1.40 * * *$ & $1.34 * * *$ \\
\hline Unfairness $*$ time interaction & & $2.89 *$ & $1.63 *$ & & & \\
\hline Marital satisfaction $*$ time interaction & & $1.82 * *$ & $2.13 * * *$ & & & $2.94 * * *$ \\
\hline Asset $*$ unfairness $*$ time interaction & & & $1.22 * *$ & & & \\
\hline Structural commitment $*$ time interaction & & & & & $2.12 * * *$ & $2.01 * * *$ \\
\hline Satisfaction $*$ structural Commitment $*$ time & & & & & & $1.48 * * *$ \\
\hline Model fit & 7997.60 & 7672.55 & 7556.50 & 7997.60 & 7915.64 & 7588.48 \\
\hline Fit improvement & & $325.05 * * * \mathrm{c}$ & $116.05 * * *{ }^{\mathrm{d}}$ & & $81.96 * * * \mathrm{c}$ & $327.16^{* * * *^{\mathrm{d}}}$ \\
\hline
\end{tabular}

${ }^{a}$ Log 10 Transform

b Omitted category $=$ White, Non-Hispanic

${ }^{c}$ Change in -2 Log Log Relative to Model 1

${ }^{\mathrm{d}}$ Change in -2 Log Log Relative to Model 2

$* p<.05 ; * * p<.01 ; * * * p<.001$

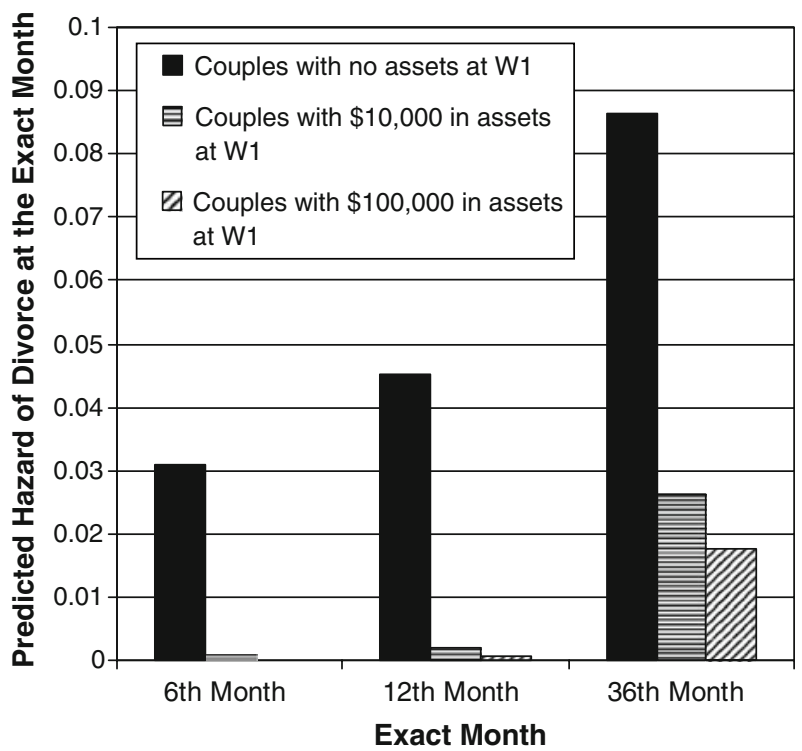

Fig. 1 The Relationship between assets and the predicted hazard of divorce at the specified month of the NSFH predicted to be 73 times more likely to divorce than individuals with $\$ 10,000$ in assets. However, by the 36th month following W1 of the NSFH, couples with no assets were only 3.3 times more likely to divorce than couples with $\$ 10,000$ in assets.

Turning to tests of the mediating variables, adding marital satisfaction and unfairness in money matters improved the model fit (Table 4, Attraction Model 2). Further, marital satisfaction negatively predicted the likelihood of divorce and adding it reduced the assets coefficient to nonsignificance. None of the hypothesized interaction variables were significant, however (Table 4, Attraction Model 3). Consequently, assets seemed to function as attractions to the marriage for wives, contrary to hypothesis $2 \mathrm{a}$, and the moderation role of financial unfairness was unsupported.

Assets functioning as barriers to divorce also received support. Again, by themselves, assets negatively predicted the likelihood of divorce (Table 3, Barrier Model 1). When 
structural commitment was added to the model, the magnitude of the asset coefficient was reduced and assets were no longer a significant predictor of divorce (Table 3, Barrier Model 2). Contrary to the idea that structural commitment only influences dissatisfied wives, however, the structural commitment by satisfaction interaction term was not significant. Thus, both satisfied and dissatisfied wives seemed to be aware that divorce might have negative consequences for their standard of living.

Like the OLS regressions, the husbands' non-proportional hazards models showed that the mechanisms that relate assets and divorce worked completely through wives. Although assets did negatively predict the likelihood of divorce for husbands, the magnitude and significance of this relationship always hovered around .92 with a statistical significance of $p<.01$ regardless of the variables added to the model (see Table 5). Consequently, husbands' characteristics did not relate assets and divorce.

\section{Discussion}

The purpose of this study was to compare three mechanisms derived from social exchange theory that might explain the negative relationship between assets and divorce. Further, this study was designed to see whether these mechanisms differed by gender. Non-proportional Cox hazards models using data from the NSFH indicated that assets were related to a lower hazard of divorce, although over time this relationship attenuated. Wives' marital satisfaction and feelings of structural commitment completely mediated this association. This suggests that assets may enhance wives' marital satisfaction so they do not want to divorce and/or raise their feelings of structural commitment to make them feel like divorce is not an option. Neither selection nor husband's characteristics played a role in the relationship between assets and divorce.

Table 5 Husbands' non-proportional hazards ratios of the relationship between assets and divorce

\begin{tabular}{|c|c|c|c|c|c|c|}
\hline & \multicolumn{3}{|c|}{ Assets as attractions to the marriage } & \multicolumn{3}{|c|}{ Assets as barriers to divorce } \\
\hline & Model 1 & Model 2 & Model 3 & Model 1 & Model 2 & Model 3 \\
\hline W1 Assets ${ }^{\mathrm{a}}$ & $.92 * *$ & $.93 *$ & $.91 * *$ & $.92 * *$ & $.93 *$ & $.93 *$ \\
\hline W1 Financial unfairness & & 1.23 & $1.33^{*}$ & & & \\
\hline W1 Marital satisfaction & & $.79 * * *$ & $.79 * * *$ & & & $.79 * * *$ \\
\hline Asset by unfairness interaction & & & 1.04 & & & \\
\hline Asset by satisfaction interaction & & & .96 & & & \\
\hline Structural commitment & & & & & .90 & .96 \\
\hline Commitment by satisfaction interaction & & & & & & 1.01 \\
\hline Family income $^{\mathrm{a}}$ & 1.03 & 1.02 & 1.02 & 1.03 & 1.02 & 1.03 \\
\hline Marital duration & $.96 * * *$ & $.96 * * *$ & $.96 * * *$ & $.96 * * *$ & $.96 * * *$ & $.97 * * *$ \\
\hline Age & $.96 * * *$ & $.96 * * *$ & $.96 * * *$ & $.96 * * *$ & $.96 * * *$ & $.96 * * *$ \\
\hline Marital number & $1.40 * * *$ & $1.44 * * *$ & $1.38 * * *$ & $1.40 * * *$ & $1.39 * * *$ & $1.39 * * *$ \\
\hline Education & $.95 * *$ & $.96 *$ & $.94 * * *$ & $.95^{* *}$ & $.95 * *$ & $.96 *$ \\
\hline Black $^{b}$ & 1.30 & 1.06 & 1.12 & 1.30 & 1.11 & 1.06 \\
\hline Other race ${ }^{b}$ & .84 & .88 & .85 & .84 & .83 & .88 \\
\hline Asset $*$ time interaction & $1.82 * * *$ & $1.67 * * *$ & $1.43 * * *$ & $1.82 * * *$ & $1.67 * * *$ & $1.58 * * *$ \\
\hline Unfairness $*$ time interaction & & $.55^{* *}$ & $.33 * * *$ & & & \\
\hline Marital satisfaction $*$ time interaction & & $1.77 * * *$ & $1.68 * * *$ & & & $1.67 * *$ \\
\hline Asset $*$ unfairness $*$ time interaction & & & $.73 * * *$ & & & \\
\hline Structural commitment $*$ time interaction & & & & & $1.77 * * *$ & $1.82 * * *$ \\
\hline Satisfaction $*$ structural commitment $*$ time & & & & & & 1.14 \\
\hline Model fit & 8033.09 & 7745.80 & 7717.66 & 8033.09 & 7987.44 & 7764.83 \\
\hline Fit improvement & & $286.68 * * * \mathrm{c}$ & $28.11 * * * \mathrm{~d}$ & & $45.24 * * * \mathrm{c}$ & $229.66 * * * d$ \\
\hline
\end{tabular}

${ }^{a}$ Log 10 Transform

b Omitted category = White, Non-Hispanic

${ }^{c}$ Change in -2 Log Log Relative to Model 1

${ }^{d}$ Change in $-2 \log \log$ Relative to Model 2

$* p<.05 ; * * p<.01 ; * * * p<.001$ 
Two reasons may explain why W1 levels of assets became less negatively predictive of divorce the longer wives remained in the study. First, the couples who went on to divorce may have decreased their asset levels between W1 and W2 and the further away from W1 couples got, the more likely they had decreased their assets. Studies have shown that couples spend down assets prior to divorce (Finke and Pierce 2006; Zagorsky 2003a). Alternatively, the interaction coefficients for marital satisfaction and time and structural commitment and time are similar to the asset by time interaction. That is, as time went on, W1 marital satisfaction and structural commitment became progressively less associated with the hazard of divorce. Thus, as time went on, wives may have reevaluated their marital satisfaction and/or structural commitment. If wives felt less satisfied or less structurally committed, then assets would be less able to negatively relate to divorce. These hypotheses about time could be tested using time varying covariates.

Finding that both structural commitment and marital satisfaction mediated the relationship between assets and divorce for women was interesting and unexpected. Unexpectedly, wives' marital satisfaction (not husbands') was a mediator. This finding suggests that wives expected their marriage to provide them with economic benefits because assets predicted marital satisfaction. Within the social exchange framework this finding indicates that when marriage delivers the economic benefits that wives expect, they are more satisfied with their marriage and less likely to divorce. Other studies do show that marriage expands women's access to higher levels of economic wellbeing such as income and assets (Hirschl et al. 2003; Light and Ureta 2004; Schmidt and Sevak 2006) and women may anticipate or expect this. As expected, however, wives are also reluctant to leave the marriage and their financial assets if they will have a lower standard or living following a divorce. The fact that structural commitment did not interact with marital satisfaction indicates that, on some level, all wives are aware of the barriers to divorce.

These two findings reveal inherent contradictions in the way money and marriage relate. Although assets are generally associated with expanded life opportunities and choices (Caputo 2003; Muntaner et al. 1998), this study shows that assets actually restrict the choice sets of women vis-à-vis divorce. Although the large majority of the women in this study were happy in their marriages, women with joint assets who were in unhappy marriages may have had to choose between living at a higher standard of living and leaving an unsatisfactory relationship. If unhappily married women chose to remain in the marriage, their physical and psychological health may have suffered (Hawkins and Booth 2005). If a woman decided to leave the marriage, then she would lose assets and live at a lower standard of living. Interestingly, however, these findings also suggest that wives expect a marriage to provide economic benefits. The result of having economic assets was not resentment for being in an economic interdependent relationship, but rather being happy with the marriage because having assets may have been meeting wives' expectations.

This study has limitations that future research needs to address before firmly concluding that assets are associated with wives' marital satisfaction and barriers to divorce. A much better test of the mechanisms would be to analyze whether changes in assets, marital satisfaction, and feelings of structural commitment are associated with the hazard of divorce. However, only having two panels and having the panels being five years apart eliminated the ability to test time varying covariates in the Cox models.

A second limitation is that another important mechanism-assets decreasing economic pressure-could not be tested with the data. Economic pressure sharply increases marital tensions and decreases positive marital interactions (Conger et al. 1994; Liker and Elder 1983). However, couples that accumulate assets report feeling less economic pressure than couples without assets, possibly because they can utilize their assets in case of economic difficulties (Conger et al. 1993; Dew 2007; Muntaner et al. 1998). Thus, couples might feel less economic pressure as they build assets, which might help them avoid divorce (Gudmunson et al. 2007). Unfortunately, because questions on couples' feelings of economic pressure were not in the first wave of the NSFH, this mechanism could not be tested against the other mechanisms.

This study contributes to knowledge of how assets and divorce relate. One contribution is simultaneously comparing the different mechanisms that link assets and divorce. Scholars have had many different suppositions for the relationship between assets and marital stability. These hypotheses were rarely tested, though, and even when they were tested, they were tested in isolation. This study was able to compare three hypotheses using the same data and show which hypotheses fit the data best. This approach is useful in sorting through the scholarly opinions that exist regarding how money and marriage are related.

Another contribution is finding that the relationship between assets and divorce works completely through wives and not husbands. This shows one way that gender is a factor in the relationship between finances and marriage, and indicates that researchers studying family finances need to thoughtfully consider how gender might play a role in family resource management. It also continues a long line of research (e.g., Tichenor 1999; Zelizer 1994) that shows that economic power imbalances in marriage offer harsher alternatives to women than to men. 
Finally, this study shows that the gendered meanings of money are by no means unidirectional (e.g., toward wives' detriment). Although wives worried about the economic consequences of divorce more than men, assets also benefited wives more than men. For example, husbands gained no relational benefit from accumulating assets but wives did. Consequently, jointly-held assets in marriage have both positive and negative meanings for wives.

Acknowledgements The author would like to thank Steve Nock and Brad Wilcox for their helpful comments on previous drafts of this study. A grant from the Social Trends Institute and from the Witherspoon Institute supported the author's efforts in this research. All analyses and interpretations are the authors' sole responsibility and may not necessarily reflect the grant-making institutions' views.

\section{References}

Allison, P. D. (1995). Survival analysis using the SAS system: A practical guide. Cary, NC: SAS Institute.

Baron, R. M., \& Kenny, D. A. (1986). The moderator-mediator distinction in social psychological research: Conceptual, strategic, and statistical considerations. Journal of Personality and Social Psychology, 51, 1173-1182.

Bianchi, S. M., Subaiya, L., \& Kahn, J. R. (1999). The gender gap in the economic well-being of nonresident fathers and custodial mothers. Demography, 36, 195-203.

Biddlecom, A. E., \& Kramarow, E. A. (1998). Household headship among married women: The roles of economic power, education, and convention. Journal of Family and Economic Issues, 19, 367-382.

Blossfeld, H.-P., \& Rohwer, G. (2002). Techniques of event history modeling: New approaches to causal analysis (2nd ed.). Mahwah, NH: Lawrence Erlbaum Associates.

Booth, A., Johnson, D. R., White, L. K., \& Edwards, J. N. (1986). Divorce and marital instability over the life course. Journal of Family Issues, 7, 421-442.

Buunk, B. P., \& Van Yperen, N. W. (1991). Referential comparisons, relational comparisons, and exchange orientation: Their relation to marital satisfaction. Personality and Social Psychology Bulletin, 6, 709-717.

Caputo, R. K. (2003). Assets and economic mobility in a youth cohort, 1985-1997. Families in Society, 84, 51-62.

Cherlin, A. J. (2004). The deinstitutionalization of American marriage. Journal of Marriage and Family, 66, 848-861.

Coleman, M., \& Ganong, L. H. (1992). Financial responsibility for children following divorce and remarriage. Journal of Family and Economic Issues, 13, 445-455.

Conger, R. D., Conger, K. J., Elder, G. H., Jr., Lorenz, F. O., Simons, R. L., \& Whitbeck, L. B. (1993). Family economic stress and adjustment of early adolescent girls. Developmental Psychology, 29, 206-219.

Conger, R. D., Ge, X. J., \& Lorenz, F. O. (1994). Economic stress and marital relations. In R. D. Conger \& G. H. Elder (Eds.), Families in troubled times (pp. 187-203). New York: Aldine de Gruyter.

Daniels, K. C., Rettig, K. D., \& delMas, R. (2006). Alternative formulas for distributing parental incomes at divorce. Journal of Family and Economic Issues, 27, 4-26.

Dew, J. P. (2007). Two sides of the same coin? The differing roles of assets and consumer debt in marriage. Journal of Family and Economic Issues, 28, 89-104.
Edin, K. (2001). What do low-income single-mothers say about marriage? Social Problems, 47, 112-133.

England, P., \& Farkas, G. (1986). Households, employment, and gender: A social, economic, and demographic view. New York: Aldine.

Fincham, F. D., \& Beach, S. R. H. (1999). Conflict in marriage: Implications for working with couples. Annual Review of Psychology, 50, 47-77.

Finke, M. S., \& Pierce, N. L. (2006). Precautionary savings behavior of maritally stressed couples. Family and Consumer Sciences Research Journal, 34, 223-240.

Fletschner, D., \& Klawitter, M. (2005). Yours, mine, and ours: How married couples hold their savings. Paper presented at the Annual Conference of the Association for Public Policy Analysis and Management, Washington DC.

Galligan, R. J., \& Bahr, S. J. (1978). Economic well-being and marital stability: Implications for income maintenance programs. Journal of Marriage and the Family, 40(2), 283-290.

Gerner, J. L., Montalto, C. P., \& Bryant, W. K. (1990). Work patterns and marital status change. Journal of Family and Economic Issues, 11, 7-21.

Gudmunson, C. G., Beutler, I. V., Israelsen, C. L., McCoy, J. K., \& Hill, E. J. (2007). Linking financial strain to marital instability: Examining the roles of emotional distress and marital interaction. Journal of Family and Economic Issues, 28, 357-376.

Hao, L. (1996). Family structure, private transfers, and the economic well-being of families with children. Social Forces, 75, 269-292.

Hawkins, D. N., \& Booth, A. (2005). Unhappily ever after: Effects of long-term, low-quality marriages on well-being. Social Forces, $84,451-471$.

Heimdal, K. R., \& Houseknecht, S. K. (2003). Cohabiting and married couples' income organization: Approaches in Sweden and in the United States. Journal of Marriage and Family, 65, 525-538.

Hirschl, T. A., Altobelli, J., \& Rank, M. R. (2003). Does marriage increase the odds of affluence? Exploring the life course probabilities. Journal of Marriage and Family, 65, 927-938.

Johnson, M. P. (1991). Commitment to personal relationships. In W. H. Jones \& D. W. Perlman (Eds.), Advances in personal relationships (Vol. 3, pp. 117-143). London: Jessica Kingsly.

Johnson, M. P., Caughlin, J. P., \& Huston, T. L. (1999). The tripartite nature of marital commitment: Personal, moral, and structural reasons to stay married. Journal of Marriage and the Family, 61, $160-177$.

Levinger, G. (1976). A socio-psychological perspective on marital dissolution. Journal of Social Issues, 32, 21-47.

Levinger, G. (1965). Marital cohesiveness dissolution: An integrative review. Journal of Marriage and the Family, 27, 19-28.

Light, A., \& Ureta, M. (2004). Living arrangements, employment status, and the economic well-being of mothers: Evidence from Brazil, Chile, and the US. Journal of Family and Economic Issues, 25, 301-334.

Liker, J. K., \& Elder, G. H., Jr. (1983). Economic hardship and marital relations in the 1930s. American Sociological Review, $48,343-359$.

Locke, H. J. (1951). Predicting adjustment in marriage: A comparison of a divorced and a happily married group. New York: Henry Holt.

McKeever, M., \& Wolfinger, N. H. (2001). Reexamining the economic costs of marital disruption for women. Social Science Quarterly, 82, 202-217.

Miller, R. S. (1997). Inattentive and contented: Relationship commitment and attention to alternatives. Journal of Personality and Social Psychology, 4, 758-766.

Morgan, L. A., Kitson, G. C., \& Kitson, J. T. (1992). The economic fallout from divorce: Issues for the 1990s. Journal of Family and Economic Issues, 13, 435-443. 
Muntaner, C., Eaton, W. W., Diala, C., Kessler, R. C., \& Sorlie, P. D. (1998). Social class, assets, organizational control and the prevalence of common groups of psychiatric disorders. Social Science and Medicine, 42, 2043-2053.

Nye, F. I. (1979). Choice, exchange, and the family. In W. R. Burr, R. Hill, F. I. Nye, \& I. L. Reiss (Eds.), Contemporary theories about the family (Vol. 2, pp. 1-41). New York: The Free Press.

Nye, F. I. (1982). The basic theory. In F. I. Nye (Ed.), Family relationships: Rewards and costs (pp. 13-31). Beverly Hills, C.A: Sage Publications.

Pollak, R. A. (1985). A transaction cost approach to families and households. Journal of Economic Literature, 23, 581-608.

Previti, D., \& Amato, P. R. (2003). Why stay married: Rewards, barriers, and marital stability. Journal of Marriage and Family, $65,561-573$.

Raudenbush, S. W., \& Bryk, A. S. (2002). Hierarchical linear models: Applications and data analysis methods. Thousand Oaks, CA: Sage Publications.

Sabatelli, R. M. (1999). Marital commitment and family life transitions: A social exchange perspective on the construction and deconstruction of intimate relationships. In W. H. Jones \& J. M. Adams (Eds.), Handbook of interpersonal commitment and relationship stability. New York: Plenum Press.

Sanchez, L., \& Gager, C. T. (2000). Hard living, perceived entitlement to a great marriage, and marital dissolution. Journal of Marriage and Family, 62(3), 708-722.

Schaninger, C. M., \& Buss, W. C. (1986). A longitudinal comparison of consumption and finance handling between happily married and divorced couples. Journal of Marriage and the Family, 48, 129-136.

Schmidt, L., \& Sevak, P. (2006). Gender, marriage, and asset accumulation in the United States. Feminist Economics, 12, $139-166$.
Smock, P. J., Manning, W. D., \& Gupta, S. (1999). The effect of marriage and divorce on women's economic well-being. American Sociological Review, 64, 794-812.

Smock, P. J., Manning, W. D., \& Porter, M. (2005). Everything's there except money: How money shapes decisions to marry among cohabitors. Journal of Marriage and Family, 67, 680-696.

Thibault, J., \& Kelley, H. H. (1959). The social psychology of groups. New York: Wiley.

Tichenor, V. J. (1999). Status and income and gendered resources: The case of marital power. Journal of Marriage and Family, 61, 638-650.

Townsend, N. W. (2002). The package deal: Marriage, work, and fatherhood in men's lives. Philadelphia: Temple University Press.

Trzcinski, E. (1996). Effects of uncertainty and risk on the allocation of time and married women. Journal of Family and Economic Issues, 17, 327-350.

Waite, L. J., \& Gallagher, M. (2000). The case for marriage: Why married people are happier, healthier, and better off financially. New York: Doubleday.

Winkler, A. E., McBride, T. D., \& Andrews, C. (2005). Wives who outearn their husbands: A transitory or persistent phenomenon for couples? Demography, 42, 523-535.

Zagorsky, J. L. (2003a). Marriage and divorce's impact on wealth. Journal of Sociology, 41, 406-424.

Zagorsky, J. L. (2003b). Husbands' and wives' view of the family finances. Journal of Socio-Economics, 32, 127-146.

Zelizer, V. A. (1994). The social meaning of money. New York: Basic Books. 